\title{
Kedaulatan Rakyat Dalam Konteks Demokrasi Di Indonesia
}

\author{
Waisol Qoroni \\ Universitas Trunojoyo Madura \\ Waisol_qoroni@gmail.com \\ Indien Winarwati \\ Universitas Trunojoyo Madura \\ indienwinarwati@gmail.com
}

\begin{abstract}
ABSTRAK
Kedaulatan rakyat yang di atur dalam Undang-Undang Dasar Negara Republik Indonesia Tahun 1945 pasal 1 ayat (2). Dalam skripsi ini membahas tentang implementasi kedaulatan rakyat yang diatur didalam UUD dalam konteks demokrasi, yang dimaksud dengan demokrasi ini yaitu berasal dari kata yunani yaitu "demos" dan "kratos" demos artinya rakyat sedangkan kratos artinya kekuasaan yang mana dapat diartikan bahwa demokrasi kekuasaannya berada ditangan rakyat. Tetapi pada masa ini tidaklah mungkin seluruh rakyat yang memegang kekuasaan atas negara maka yang dilaksanakan oleh negara adalah demokrasi dengan sistem perwakilan. Di Indonesia kedaulatan rakyat berdasarkan UUD NRI Tahun 1945 pasal 1 ayar (2) yang dilaksanakan oleh DPR melalui kinerja DPR yaitu seperti Focus Group Discussion (FGD), parlemen kampus dan parlemen remaja diilihat dari kinerja DPR yang melaksanakan kedaulatan rakyat belum maksimal karena belum merata dan masyarakat banyak yang tidak mengetahui karena DPR hanya mengadakan diskusi dan meminta pendapat dari masyarakat kampus yang dianggap ahli, dan juga dalam bentu pembentukan perundang-undangan bahwasannya DPR mempunyai kewenangan untuk membentuk undang-undang sedangkan masyarakat juga dapat perbartisipasi dalam pembentukan peraturan perundang-undangan dengan cara-cara yang sudah ditentukan dan juga masyarakat juga dapat berpartisipasi dengan tiga metode yaitu metode Ante Legislative, Legislative dan Post Legislativ.
\end{abstract}

Kata kunci : Kedaulatan rakyat, DPR, Undang-undang Dasar NRI Tahun 1945.

\begin{abstract}
Sovereignty of the people governed in the 1945 Constitution of the Republic of Indonesia Article 1 paragraph (2). In this thesis discusses the implementation of people's sovereignty regulated in the Constitution in the context of democracy, what is meant by democracy is derived from the Greek words "demos" and "kratos" domos means the people while kratos means power which can be interpreted that democracy is in the hands of power people. But at this time it is not possible for all the people who hold power over the state to carry out by the state is democracy with a representative system. In Indonesia, the sovereignty of the people based on the 1945 Constitution of the Republic of Indonesia 1945 Article 1 paragraph (2) carried out by the DPR through the performance of the DPR, such as Focus Group Discussion (FGD), campus and youth parliaments, is seen from the performance of the DPR which implements the people's sovereignty is not optimal because it is not evenly distributed and many people do not know because the DPR only holds discussions and solicits opinions from campus people who are considered experts, and also in the form of legislation formation that the DPR has the authority to form laws while the public can also participate in the formation of legislation by -the predetermined way and also the public can also participate with three methods namely the Ante Legislative, Legislative and Post Legislative methods.
\end{abstract}

Keywords: People's sovereignty, Parliament, 1945 Constitution of the Republic of Indonesia. 


\section{PENDAHULUAN}

Negara dapat terbentuk apabila sudah memenuhi syarat, salah satunya adalah syarat pemerintahan dan kedaulatan. Kedaulatan adalah berawal dari terjemahan bahasa inggris "sovereignty", dan dalam bahasa prancis "souverainete". Konsep ini berawal dari bahasa latin "superanus" yang mempunyai arti tertinggi. 1 Para ahli kenegaraan dan hukum pada masa abad pertengahan, menggunakan makna "superanus" dengan istilah "summa potestas" dalam arti kedaulatan tertinggi dari suatu kesatuan politik. Dalam UUD NRI Tahun 1945 pasal 1 ayat (2) berbunyi "kedaulatan berada di tangan rakyat dilaksanankan merurut undang-undang dasar" belum ada penjelasan mengenai kedaulatan seperti apa yang berada di tangan rakyat maka dari itu artikel ini membahas kedaulatan seperti apa yang berada di tangan rakyat apa seluruh rakyat yang memegang kekuasaan tertinggi atau berbasis perwakilan dan bagaimana rakyat tetap mendapatkan haknya sebagai pemegang kekuasaan tertinggi menurut UUD.

Hakikat Kedaulatan ialah konsep tentang kekuasaan tertinggi didalam sebuah negara dan tidak dapat dikurangi atau diintervensi oleh negara lain. Didalam analisa tentang konsep kekuasaan, ide atas kedaulatan yang menjadi konsep tentang kekuasaan tertinggi mencakup pelaksaan pengambilan keputusan. Yang bisa menjadi persoalan, seperti keputusan yang sudah di tetapkan mempunyai kekuatan

\footnotetext{
1 Mohamad Faisal Ridho, Journal "Adalah" "Kedaulatan Rakyat Sebagai Perwujudan Demokrasi Indonesia" Volume 1 Nomor 8e, Tahun 2017, hlm 79.
}

seberapa besar, baik dilapangan legislatif ataupun eksekutif. Tetapi dalam jangkauan kedaulatan, berdasarkan analisis relasional antara sovereign juga subjeck, mengenai tentang soal siapa yang menjadi subjek atau apa yang dapat mempunyai kekuasaan tertinggi didalam negara. ${ }^{2}$ Yang dimaksud dengan hakekat negara bukanlah hakekat negara tertentu, melainkan hakekat dari apa yang dinamakan negara itu sendiri, hakekat negara plato berpendapat "negara itu dapat diukur atau disesuaikan dengan dapat atau tidaknya, mampu atau tidaknya negara memelihara kesatuan didalam negara tersebut, karena negara itu dapat dikatakan adalah suatu keluarga yang besar. 3

Indonesia sendiri merupakan salah satu negara yang menganut sistem demokrasi. Paham tersebut terurai secara konstitusional dan fundamental dalam Pembukaan Undangundang Dasar NRI Tahun 1945 alenia IV, yang menegaskan salah satu dasar negara yang berbunyi: "Kerakyatan yang dipimpin oleh hikmat kebijaksanaan dalam permusyawaratan/perwakilan".4 Berdasarkan data yang dikumpulkan oleh Ahmad Budiman dalam jurnalnya yang berjudul “Optimalisasi Penanganan Surat Pengaduan Mayarakat Ke DPR RI". Pada tahun 2006 sejumlah 371 (tiga

2 Moh. Kusnardi dan Harmaily Ibrahim, Pengantar Hukum Tata Negara Indonesia, Jakarta, Pusat Studi Hukum Tata Negara, 1983, hlm.72.

3 Soehino, Ilmu Negara, Yogyakarta, Liberty, 2001, hlm.17.

4 Mohamad Faisal Ridho, "Kedaulatan Rakyat Sebagai Perwujudan Demokrasi Indonesia”, Jurnal Adalah : Vol. 1 Nomor 8e, 2017, hlm.79. 
ratus tujuh puluh satu) surat, lebih rendah dari penerimaan surat pengaduan masyarakat pada tahun sebelumnya sebanyak 488 (empat ratus delapan puluh delapan) surat.

Berdasarkan data tersebut dapat kita ketahui, bahwa pada tahun 2006 bidang masalah peradilan/pelanggaran hukum adalah bidang masalah yang paling banyak disampaikan masyarakat melalui surat pengaduan masyarakat kepada DPR RI sebanyak 132 (seratus tiga puluh dua surat) $(35,58 \%)$. Selanjutnya surat pengaduan masyarakat bidang masalah pertanahan sebanyak 81 (delapan puluh satu) surat $(21,8 \%)$ adalah bidang masalah berikutunya yang banyak disampaikan masyarakat ke DPR RI. Sedangkan surat pengaduan masyarakat untuk bidang masalah keuangan dan ekonomi paling sedikit masing-masing berjumlah 2 surat $(0,54 \%)$ disampaikan masyarakat ke DPR RI. Seperti juga pada tahun 2005, maka pada tahun 2006 tindaklanjut surat pengaduan masyarakat oleh DPR RI juga tidak sebanding dengan surat pengaduan masyarakat yang diterima oleh DPR RI. Jumlah surat pengaduan masyarakat yang diterima DPR RI sejumlah 371 (tiga ratus tujuh puluh satu) surat pengaduan, hanya mampu ditindaklanjuti oleh DPR RI sebanyak 288 (dua ratus delapan puluh delapan) surat pengaduan masyarakat.

Surat pengaduan masyarakat untuk bidang masalah peradilan/pelanggaran hukum hanya mampu ditindaklanjuti sebanyak 55 (lima puluh lima) surat pengaduan dari 132 (seratus tiga puluh dua) surat pengaduan masyarakat yang diterima DPR RI. Pada tahun 2007 surat pengaduan masyarakat yang diterima DPR RI berdasarkan bidang masalah berjumlah 356 (tiga ratus lima puluh enam) surat pengaduan masyarakat dan ditindaklanjuti oleh Dewan sebanyak 122 (seratus dua belas) surat pengaduan masyarakat. Surat pengaduan masyarakat yang ditindaklanjuti oleh DPR RI hanya mencapai $31,46 \%$ dari jumlah surat pengaduan masyarakat yang diterima DPR RI. Sedangkan pada tahun 2008 surat pengaduan masyarakat yang diterima DPR RI berdasarkan bidang masalah berjumlah 265 (dua ratus enam puluh lina) surat pengaduan masyarakat dan ditindaklanjuti oleh Dewan sebanyak 232 (dua ratus tiga puluh dua) surat pengaduan masyarakat. Meski mampu menindaklanjuti surat pengaduan masyarakat sebanyak $87,54 \%$ dari surat pengaduan masyarakat yang diterima DPR RI, namun jumlah surat pengaduan masyarakat yang diterima DPR RI sangat sedikit sekali.

\section{METODE PENELITIAN}

Metode penelitian merupakan cara atau peran penting dalam mencapai suatu tujuan penulisan, termasuk dalam suatau metode yang akan ditulis, metode yang dimaksud adalah cara-cara untuk melaksanakan penelitian berdasarkan data-data atau fakta yang telah ada. Dalam penyusunan penelitian, penulis menggunakan metode penelitian sebagai berikut :

1. Jenis Penelitian, Jenis penelitian didalam penulisan penelitian ini memakai jenis penelitian hukum normatif. Menurut Mukhti Fajar dan Yulianto Ahmad 
penelitian hukum normatif ialah penelitian yang menggunakan hukum sebagai bangunan sistem norma. Maksud dari sistem norma ini adalah asas-asas, peraturan perundang-undangan, putusan pengadilan, perjanjian dan $\operatorname{dotrik}^{5}$. Sedangkan penelitian normatif bisa juga dikatakan sebagai penelitian dengan bahan kepustakaan. Metode penelitian ini mengkaji "Undang-Undang Dasar Negara Republik Indonesia Tahun 1945 Pasal 1 Ayat (2)" tentang kedaulatan rakyat dalam ketatanegaraan Indonesia. Secara Normatif, Metode penelitian hukum normatif ialah cara yang dipergunakan didalam penilitian hukum yang dilakukan dengan cara meniliti bahan pustaka.

2. Pendekatan Penelitian, Berdasarkan pada rumusan masalah dan pada tujuan permasalahan maka penelitian ini menggunakan metode pendekatan perundang-undangan yaitu metode pendekatannya berdasarkan undang-undang atau peraturan lainnya. Pendekatan ini misalnya dilasanakan dengan mempelajari konsistensi atau sejalan antara UUD "NRI" Tahun 1945 dengan undang-undang nomor 71 tahun 2014 tentang MD3, atau antara undang-undang. 6

5 Mukhti Fajar dan Ahmad Yulianto, Dualisme Penelitian Hukum Normatif dan Empiris, Yogyakarta, Pustaka Pelajar, 2013, hlm.34.

6 Peter Mahmud Marzuki, Penelitian Hukum, Jakarta, Kencana, 2016, hlm.133.

\section{HASIL DAN PEMBAHASAN}

1. Pelaksana Kedaulatan Rakyat

\section{Berdasarkan Konstitusi Indonesia}

Pelaksanaan kedaulatan rakyat yang dulunya dilaksanakan oleh MPR seutuhnya yang merupakan lembaga negara tertinggi berdasarkan UUD NRI Tahun 1945 (Naskah Asli) tetapi dalam perubahan UUD NRI Tahun 1945 yang membuat kedudukan MPR dari lembaga tertinggi menjadi lembaga tinggi negara yang status kedudukannya sama dengan lembaga negara lainnya, jadi dalam melaksanakan kedaulatan rakyat yang berdasarkan UUD NRI Tahun 1945 dalam perubahannya yang melaksanakan kedaulatan rakyat bukanlah hanya MPR tetapi semua lembaga negara yang mengemban tugas dan kewajiban politik negara dan pemerintahan. 7

MPR dalam salah satu sidang gabungannya antara DPR dan DPD yang mana DPR yang mengemukakan kepentingan rakyat secara umum sedangkan DPD sebagai penyalur aspirasi daerahnya, sidang gabungan ini dilaksanakan apabila menyangkut kewenangan DPR dan DPD sedangkan dalam kewenangan MPR dalam pasal 3 UUD NRI Tahun 1945 dalam pengambilan keputusan bukan berasal dari sidang gabungan melainkan kewenangan MPR dan sidang MPR sebagai lembaga tersendiri. Menurut Jimly Assiddiqie dalam

7 Yusdar, "Format Kelembagaan dan Politik Hubungan MPR Dengan DPR dan DPD Pasca Amandemen UUD Tahun 1945”, Jurisprudentie, Vol. 3 Nomor 2, Kab. Maros, 2016, hlm.164. 
bukunya yang berjudul "Pokok-pokok Hukum Tata Negara Indonesia Pasca Reformasi" kedudukan MPR termasuk dalam struktur parlemen Indonesia yang menjadi lembaga ketiga dalam parlemen sehingga di Indonesia dalam sistem parlemen lebih cocok dengan sistem tiga kamar (trikameralisme) yang mana Indonesia merupakan negara satu-satunya yang menggunakan sistem tiga kamar dan tidak ada satupun negara yang menerapkan sistem tiga kamar ini. 8

Indonesia menganut paham kedaulatan rakyat yang mana tercantum dalam konstitusi Indonesia yaitu UUD NRI Tahun 1945 dalam kekuasaan yang sesungguhnya berasal dari rakyat, oleh rakyat dan untuk rakyat dalam penyelenggaraan kekuasaan ini dilakukan bersama-sama langsung dengan rakyat sesuai dengan prosedur konstitusi indonesia, sedangkan indonesia sendiri juga menganut paham kedaulatan hukum yang dalam pelaksaannya dilakukan secara bersama-sama dengan kedaulatan rakyat. Dengan sangat jelas indonesia ini termasuk negara hukum yang demokrasi dalam penerapannya tidak dapat dipisahkan. 9 Dalam negara Indonesia kedaulatan berada di tangan rakyat sudah jelas dalam pasal 1 ayat (2) Undang-undang Dasar Negara Republik Indonesia tetapi pada sejarahnya

8 Ibid, hlm.165.

9 Halmes Lekipiouw Sherlock, "Konstruksi Kelembagaan Perwakilan Dalam Pelaksanaan Kedaulatan Rakyat", Sasi, Vol. 24 Nomor 1, Tahun, 2016, hlm.79. penyelenggara kedaulatan rakyat yang pertama adalah Majelis Permusyawaratan Rakyat tetapi dalam amandemen yang ke tiga dalam penyelenggara kedaulatan rakyat adalah undang-undang dasar itu sendiri.

Untuk menyelenggarakan kedaulatan rakyat ada perubahan didalam konstitusi negara Indonesia yaitu dalam pasal 1 ayat (2) Undang-undang dasar negara republik Indonesia tahun 1945 yang berbunyi "kedaulatan adalah di tangan rakyat dan dilakukan sepenuhnya oleh majelis permusyawaratan rakyat" dalam pasal ini dikemukaan oleh Yamin dalam sidang Badan Penyelidik Usaha-usaha Persiapan Kemerdekaan Indonesia (BPUPKI) pada tahun 1945 bulan juli tanggal 11 menyatakan bahwa pada saat itu belum di bentuk panitia perancang undang-undang dasar. Yang di dalam pernyataannya Yamin ingin menjadikan majelis permusyawaratan rakyat (MPR) sebagai lembaga tertinggi dan para peserta BPUPKI bertepuk tangan dengan pernyataan yang di sampaikan oleh Yamin yang mana tepuk tangan ini ditafsirkan bahwa peserta BPUPKI menyetujui. 10 Dan pada tanggal 13 juli 1945 panitia perancang undang-undang dasar yang diketuai oleh Soepomo dan dipimpim oleh Soekarno yang sekaligus menjadi Ketua panitia perandang undangundang dasar, bahwa dalam pasal 1 ayat (2) UUD NRI Tahun 1945 menyebutkan bahwa MPR sebagai penyelenggara kedaulatan

10 Anwar, Teori dan Hukum Konstitusi, Malang, Setara Press, Tahun 2015, hlm.156. 
rakyat. 11

Majelis Permusyawaratan Rakyat (MPR) adalah lembaga tertinggi di Indonesia sebelum Undang-undang Dasar Negara Republik Indonesia Tahun 1945 di amandemen kedudukan MPR sebagai lembaga tertinggi memliki kedudukan yang sangat penting yakni:

a. Majelis Permusyawaratan Rakyat mengatur dan menentukan kekuasaan lembaga negara lainnya seperti DPR, Presiden dan MA melalui penetapan dan perubahan UUD NRI Tahun 1945;

b. Majelis Permusyawaratan Rakyat membuat pedoman yang lebih rinci untuk dijadikan landasan bagi lembaga negara lainnya dalam menjalankan kekuasaan lembaga negara dalam bentuk ketetapan majelis permusyawaratan rakyat (MPR);

c. Majelis Permusyawaratan Rakyat sekaligus mempunyai fungsi pengawasan bagi lembaga lainnya yang mempunyai kekuasaan dan apakah lembaga negara yang mempunyai tugas yang diberikan sudah berjalan sesuai dengan UUD NRI Tahun 1945 dan Tap MPR, dan lembaga negara yang memiliki tugas dari MPR mempunyai kewajiban untuk memberikan laporan mengenai

11 Ibid, hlm.159. tugasnya kepada MPR. 12

Kekuasaannya MPR sebagai lembaga tertinggi yang menjadi pelaksana sepenuhnya kedaulatan rakyat dalam pasal 1 ayat (2) Undang-undang Dasar NRI Tahun 1945 bahwa kedaulatan berada di tangan rakyat dan di amanahkan sepenuhnya kepada MPR, yang mana dalam amanahnya MPR memberikan tugas kekuasaannya kepada lembaga negara lainnya. Dahlan Thalib merumuskan delegasi kekuasaan MPR dalam rincian :

a. Kewenangan Eksekutif diberikan kepada Presiden dalam pasal 4 ayat (1) UUD NRI Tahun 1945;

b. Kewenangan Legislatif diberikan kepada DPR dan Presiden dalam pasal 5 ayat (1) UUD NRI Tahun 1945;

c. Kewenangan Yudikatif diberikan kepada Mahkamah Agung (MA) dalam pasal 24 ayat (1) UUD NRI Tahun 1945;

d. Kewenangan Inspektif diberikan kepada DPR dan BPK. Yaitu DPR mempunyai fungsi pengawasan terhadap kewenangan eksekutif, dan BPK mempunyai tugas untuk memeriksan dan bertanggung jawab atas keuangan negara, dan hasil pengawasannya diberi tahukan kepada DPR dalam pasal 23 ayat (5) UUD NRI Tahun 1945;

e. Kewenangan Konsultataif diberikan kepada Dewan Pertimbangan Agung

12 Ibid, hlm. 163. 
(DPA) dalam pasal 16 UUD NRI

Tahun 1945. 13

Berbeda dengan pendapat Dahlan Thalib Menurut Padmo Wahyono dalam kedaulatan atau kekuasaan tertinggi adalah rakyat dan sesuai UUD NRI Tahun 1945 dikuasi oleh rakyat dan rakyat mewakilkan kedaulatannya kepada MPR dalam tugas yang di tentukan yaitu pembuatan UUD, rakyat juga mewakilkan kedaulatannya kepada Presiden dan DPR dalam tugas yang sudah di tentukan, dan juga kepada MA rakyat mewakilkan kedaulatannya kepada MA dalam melaksanakan fungsi kehakiman, dan rakyat juga mewakilkan kedaulatannya kepada BPK dalam masalah keuangan, segala pelimpahan kedaulatan yang diberikan oleh rakyat kepada lembaga-lembaga negara berdasarkan undang-undang. 14

Perubahan pasal 1 ayat (2) UUD NRI Tahun 1945 sebagai salah satu tuntutan reformasi dimana MPR sebagai lembaga tertinggi negara dianggap sebagai penjelmaan dari rakyat yang seharusnya rakyat memiliki kedaulatan tertinggi beralih kepada MPR hal ini menjadi perbincangan dalam para ahli hukum tata negara Indonesia yang pada dasarnya MPR hanya sebagai lembaga pelaksana kedaulatan rakyat tetapi kedudukan MPR dianggap sebagai kedaulatan MPR, dan hal ini menjadi sebab atas tuntutan reformasi pada pasal 1 ayat (2) UUD NRI Tahun

13 Ibid, hlm.164.

14 Ibid, hlm. 165.
1945.15 Dalam perubahan undang-undang dasar negara republik Indonesia tahun 1945 yang ke tiga salah satunya perubahan atas pasal 1 ayat (2) yang sebelumnya berbunyi "kedaulatan adalah di tangan rakyat di lakukan sepenuhnya oleh majelis permusyawaratan rakyat" menjadi "kedaulatan berada di tangan rakyat dan dilaksanakan menurut undang-undang dasar" perubahan pasal ini salah satu tuntutan revormasi karena dianggap MPR sebagai lembaga tertinggi memiliki supremasi MPR, dan MPR disebut-sebut sebagai penjelmaan rakyat, perubahan ini diajukan oleh Panitia Ad Hoc (PAH) Badan Pekerja (PB) Majelis Permusyawaratan Rakyat (MPR) yang selanjutnya disebut PAH I PB MPR yang mana dikala itu MPR memiliki tujuan untuk memperbaiki hubungan antara legislatif (DPR) dengan eksekutif (presiden). ${ }^{16}$ Dan pada sidang tahunan MPR RI dalam perubahan UUD NRI Tahun 1945 yang ke tiga yaitu pada bulan November tahun 2001 yang mana dikala itu PAH I BP MPR menyiapkan materi sidang tentang "kedaulatan permusyawaratan rakyat" dan dalam hasil rapat sidang UUD NRI Tahun 1945 amandemen ke tiga dalam pasal 1 ayat (2) disepakati dan menghasilkan "kedaulatan berada di tangan rakyat dan dilaksanakan menurut undang-undang dasar. ${ }^{17}$

Perubahan undang-undang dasar negara

15 Anwar, Teori dan Hukum Konstitusi, Malang, Setara Press, 2015, hlm.168.

16 Ibid, hlm. 168.

17 Ibid, hlm.175. 
republik indonesia tahun 1945 pasal 1 ayat (2) menurut Soewoto merupakan cerminan dari keadaan yang sebenarnya dalam kekuasaan tertinggi negara, yang berarti merealistikkan prinsip tatanegara yang menampung sekaligus kedaulatan rakyat, kedaulatan hukum, kedaulatan negara dan kedaulatan parlemen.

Jadi menurut Soewoto yang meneliti perubahan atas pasal 1 ayat (2) UUD NRI Tahun 1945 menganut kedaulatan rakyat yang dapat di terima oleh rakyat dan sekaligus menganut kedaulatan hukum yang mana atas perintah selanjutnya yang "dilaksanakan berdasarkan Undang-undang Dasar ini" mengandung unsur kedaulatan hukum yaitu dasar aturan yang menjadi pelaksana kedaulatan rakyat adalah supremasi Undang-undang Dasar. Tetapi terjadi penolakan atas pendapat dari Soewoto mengenai pasal 1 ayat (2) yang mengandung kedaulatan negara dan kedaulatan parlemen.

Menurut penulis kedaulatan yang di atur dalam UUD Tahun 1945 pasal 1 ayat (2) yang mana kedaulatan berada di tangan rakyat dan laksanakan oleh UUD di jalankan dengan sistem kedaulatan perwakilan mana kedaulatan tersebut diwakikan kepada wakil rakyat (DPR). tetapi meskipun DPR yang mewakili rakyat sebagai pemegang kedaulatan bukan berarti rakyat tidak mempunyai hak untuk ikut serta dalam setiap keputusan dan kebijakan serta setiap tindakan wakil rakyat, rakyat tetap memiliki haknya sebagai pemegang kedaulatan.

\section{Partisipasi Masyarakat Dalam Kinerja DPR}

Menjamin hak rakyat tidak diabaikan maka rakyat juga mempunyai peran penting dalam kinerja para wakilnya hal ini bertujuan untuk tidak mengabaikan kepentingan rakyat dan juga hak rakyat sehingga kinerja DPR sebagai perwakilan dari rakyat mempunyai tindakan juga keputusan yang mementingkan rakyat. Berikut adalah wujud program kerja yang dilakukan oleh DPR yang seharusnya melibatkan masyarakat umum;

\section{a. Focus Goup Discussion (FGD)}

Focus Group Discussion yang selanjutnya akan disebut dengan (FGD) atau Diskusi Kelompok Terarah merupakan bentuk kegiatan pengumpulan data melalui wawancara kelompok dan pembahasan dalam kelompok sebagai alat/media paling umum digunakan dalam metode Participatory Rural Appraisal (PRA) atau pemahaman partisipatif kondisi pedesaan maupun metode ZOPP adalah motode perencanaan proyek yang dikembangkan. 18

Berdasarkan teori dan penjelasan tentang FGD diatas dan dianalisi dengan penerapan FGD yang dilakukan oleh DPR pada tahun 2019 tepatnya pada tanggal 27 bulan Februari yang dilaksanakan oleh DPR dengan bekerjasama dengan Lembaga Penelitian dan Pengabdian Kepada Masyarakat (LPPM) yang

18 Edi Indrizal, "Diskusi Kelompok Terarah Focus Group Discussion (FGD) (Prinsip-prinsip dan Langkah Pelaksanaan Lapangan), Universitas Andalas, Padang, 2014) hlm.75. 
diselenggarakan di Universitas Diponegoro, Semarang, Jawa Tengah, dalam rangka FGD "Rancangan Undangundang Energi Baru dan Terbaru (RUU EBT)"'.

Bahwasannya DPR melakukan wujud program kerjanya hanya melalui kehidupan kampus dan hanya meminta pendapat dari akademisi dan yang dianggap ahli seperti Dosen, hal ini menunjukkan bahwa FGD yang diterapkan oleh DPR belum optimal karena undangundang jangkauannya luas dan menyeluruh sedangkan dalam penyebarluasannya dan diskusinya hanya dikalangan atas, dan menimbulkan kalangan pedesaan dan area yang jauh dari kampus atau universitas tidak mengetahui.

\section{b. Parlemen Kampus}

DPR mengadakan kegiatan Parlemen Kampus hal ini bertujuan untuk; menurut Kepala Biro Pemberitaan Sekretariat Jendral (setjen) dan Badan Keahlian (BK) DPR RI, Y.O.I Tahapari pada tanggal 31 januari Tahun 2020 bertempatan di Universitas Swadaya Gunung Jati, Kota Cirebon menyatakan dalam pidatonya bahwa parlemen kampus ini bertujuan untuk memberikan pemahaman tentang proses demokrasi yang berlansung di parlem juga proses politik yang ada di parlemen.

Parlemen kampus ini hanya fokus dikalangan mahasiswa kampus yang merupakan kegiatan rutin DPR, parlemen kampus juga bertujuan untuk lebih mengetahui kinerja DPR RI dan juga diharapkan peserta dari parlemen kampus mendapatkan manfaat. Agenda parlemen kampus ini juga dirasa belum maksimal meskipun bertujuan untuk lebih mengetahui kinerja DPR dan sebaginya tetapi tidak semua kampus mempunyai kesempatan berpartisipasi dalam acara DPR ini bahkan kampus yang dapat mengikuti acara ini tidak semua mahasiswa berkesempatan ikut karena jumlah yang terbatas.

\section{c. Parlemen Remaja}

Parlemen remaja dilaksanakan karena adanya amanat dari Asosiasi Parlemen Dunia yaitu Inter-Parliamentary Union yang selanjutnya disebut dengan (IPU) yang menetapkan pada tanggal 15 september sebagai "International Day of Democracy" Indonesia sebagai bagian dari anggota IPU dan diamanatkan untuk menyelenggarakan kegiatan parlemen remaja sebagai wahana pendidikan demokrasi. Oleh karena itu sekretariat jenderal dan badan keahlian DPR RI, melalui biro pemberitaan parlemen mengadakan kegiatan parlemen remaja yang diadakan tiap tahun semenjak tahun 2008. Yang mana dalam penyelenggaraan parlemen remaja ini bertujuan untuk; a) Memasyarakatkan fungsi dan peranan DPR kepada remaja sebagai generasi penerus bangsa. b) Memberikan pemahaman kepada remaja (siswa/siswi SMU/SMK) tentang proses pembuatan kebijakan publik di parlemen. c) Meningkatkan pemahaman remaja tentang proses demokrasi di 
Indonesia melalui pelaksanaan simulasi parlemen. manfaat bagi Dewan Perwakilan Rakyat dalam kegiatan remaja parlemen: a) Sosialisasi mekanisme persidangan di DPR.

b) Mengembangkan relasi komunikasi antara DPR dengan pelajar se Indonesia. c) Membangun citra positif tentang parlemen.

d) Mendekatkan parlemen dengan generasi muda. 19 Sesuai dengan tujuan dari penyelenggaraan parlemen remaja ini dan manfaat bagi DPR yang dijelaskan dalam situs resmi DPR bahwasannya dalam praktiknya belum juga merata karena yang seharusnya terselenggara dari tahun 2008 mestinya sampai sekarang seharusnya sudah merata dan diketahui oleh masyarakat pada umumnya, sedangkan disini peneliti baru mengetahui adanya agenda DPR di sekolah tingkat akhir ini. Jadi parlemen remaja ini juga belum maksimal penerapannya.

\section{Wujud Kedaulatan Rakyat Dalam} Pembentukan Peraturan Perundangundangan

Mewujudkan kedaulatan rakyat pada bidang pembentukan peraturan perundangundangan yang dalam pembuatan undangundang ini dilaksanakan oleh DPR berdasarkan pasal 20 ayat (1) UUD Negara Republik Indonesia Tahun 1945 sebagai amanat dari UUD DPR mempunyai

19 Dewan Perwakilan Rakyat, "Parlemen Remaja”, dikutip

dari http://www.dpr.go.id/parlemen-remaja/index diakses pada 8 mei 2020 jam. 01:46. kewajiban untuk merancang undangundang. Tetapi didalam UUD Negara RI Tahun 1945 sebelum di amandemen pasal 5 ayat (1),(2) dalam pembentukan peraturan perundandang-undangan presiden yang mempunyai kekuasaan dan presiden juga berhak mengajukan rancangan kepada DPR.

a. Kewenangan Pembentukan Undangundang

Kekuasaan dalam pembentukan peraturan perundang-undangan yang semula dijalankan oleh presiden berdasarkan pasal 5 UUD Tahun 1945 (sebelum amandemen) pada amandemen ke empat kekuasaan dalam pembentukan peraturan perundang-undangan dilaksanakan oleh DPR berdasarkan UUD Tahun 1945 dan pasal 5 ayat (1) dihapus, hal ini sebagai wujud dari langkah konstitusional yang bertujuan untuk memperbaiki fungsi dari lembaga negara sesuai dengan tugas dan wewenang masing-masing lembaga yang mana presiden sebagai pelaksana UU (Eksekutif) dan DPR sebagai pembentuk UU dan memperkuat kekuasaan DPR sebagai Legistif. 20

Untuk menyusun peraturan perundang-undangan DPR yang diperintahkan oleh UUD yang selanjutnya diatur dalam UU No. 13 Tahun 2019 Jo UU No. 17 Tahun 2014

20 Ni'matul Huda, Hukum Tata Negara Indonesia, Jakarta, Pt Raja Grafindo Persada, 2005, hlm.177. 
tentang MD3 yang mana salah satu tugas DPR berdasarkan pasal 72 UU MD3 adalah menyusun dan membahas rancangan UU serta menyebarluaskan, adapun rancangan UU ini dilakukan oleh DPR atau Presiden berdasarkan UUD 1945 (amandemen) pasal 5 dan 20 yang selanjutnya ditampung oleh Badan Legislasi yang selanjutnya akan dibahas dengan memanggil pihak pemrakarsa dan lembaga terkait.

b. Pastisipasi Masyarakat Dalam

\section{Pembentukan Undang-undang}

Ada perbedaan antara partisipasi masyarakat dalam pembentukan UU dengan aspirasi dan pengaduan masyarakat kepada DPR, meskipun partisipasi dalam pembentukan peraturan UU dapat dilakukan melalui ketentuan aspirasi dan pengaduan masyarakat, berdasarkan pasal 96 Undang-undang RI Nomor 12 Tahun 2011 Tentang Pembentukan Peraturan Perundangundangan $\mathrm{BAB}$ XI pasrtisipasi masyarakat, dapat memberi masukan terhadap pembentukan peraturan perundang-undangan ada 4 cara yaitu: 1) Dengan menghadiri rapat dengar pendapat umum (RDPU); 2) Dengan melakukan kunjungan kerja; 3) Dengan menghadiri sosialisasi; 4) Dengan menghadiri seminar atau diskusi/lokakarya.

Masyarakat dapat memberikan masukan sedangkan tidak mengetahui tentang rancangan UU ? ini adalah tugas dari DPR dan lembaga terkait mengenai penyebarluasan rancangan UU, Sebelum masyarakat ikut serta dalam pembentukan peraturang perundangundangan ada tahapan penyebarluasan rancangan undang-undang yang mana hal ini di atur dalam pasal 88 sampai pasal 90 UU RI No. 12 Tahun 2011 Tentang pembentukan peraturan perundangundangan, penyebarluasan ini dimulai dari tahap penyusunan dan pembahasan rancangan UU dapat melalui media elektronik maupun dari media cetak. 21

Penyampaian partisipasi oleh masyarakat dalam pembentukan undangundang dapat dilakukan dengan berkelompok atau dengan individu, meskipun ada kemiripan dalam metode ini tetapi tidak sama, dalam menyampaikan keinginan masyarakat dalam pembentukan perundangundangan ada tiga metode yaitu: 1) Metode Ante Legislative. a) Penelitian: Masyarakat dapat melakukan partisipasi dengan melakukan penelitian terlebih dahulu hal ini dapat dilakukan ketika ada persoalan dalam kehidupa bermasyarakat maupun bernegara penelitian yang dilakukan oleh masyarakat bertujuan sebagai dasar untuk dikaji dan membutuhkan penyelesaian melalui undang-undang. b) Diskusi, seminar dan lokakarya : Diskusi, seminar dan

21 Kementerian Hukum dan HAM, Tanya Jawab Seputar Pembentukan Peraturan Perundangundangan, Kemenkumham, Jakarta, 20119, hlm.85. 
lokakarya ini dapat dibilang tindak lanjut dari penelitian yang dilakukan oleh masyarakat terkait rancangan undangundang. c) Usul inisiatif : Partisipasi masyarakat melalui tahap usul inisiatif ini dapat dilakukan dengan tidak melakukan kedua tahapan diatas yaitu penelitian dan diskusi, tetapi usul inisiatif ini akan lebih kuat apabila sudah melakukan penelitian dan diskusi. d) Dalam bentuk peracangan terhadap undang-undang : Tahapan ini merupakan tahap akhir untuk masyarakat yang berparsipasi dalam pembentukan UU dengan menggunakan metode ante legislative dengan arti telah melakukan penelitian dan usulan inisiatif, dengan begitu masyarakat dapat memasukkan hasil dari penelitian kedalam rancangan undang-undang, untuk itu disarankan membuat naskah akademik untuk rancangan undang-undang. 22 2) Metode Legislative. a) Bentuk audensi/rapat dengar pendapat umum : Ikut serta dalam rapat dengar pendapat umum yang selanjutnya disebut dengan (RDPU) dapat dilakukan dengan kemauan sendiri atau undangan dari DPR, masyarakat dapat menyampaikan keinginannya kepada wakil rakyat yang akan ditampung oleh DPR. b) Bentuk rancangan undang-undang alternatif :

22 Putera Astomo, "Pembentukan UndangUndang Dalam Rangka Pembaharuan Hukum Nasional Di Era Demokrasi", Jurnal Konstitusi, Vol. 11, Nomor 3, Tahun 2014, hlm.593.
Masyarakat dapat menyalurkan pendapat tentang rancangan undang-undang dengan membuat rancangan undangundang alternatif apabila rancangan undang-undang yang dibahas tidak sejalan dengan keadaan dan keingin masyarakat. c) Bentuk masukan dari media cetak : Media cetak dapat menjadi saluran partisipasi bagi masyarakat terkait masalah yang dibahas di DPR, yang dapat berupa artikel atau opini dan juga dapat berupa pertanyaan-pertanyaan di koran, majalah dan media cetak lainnya. d) Bentuk masukan dari media elektronik : Media elektronik juga bisa menjadi sarana penyampaian partisipasi dalam masalah yang dibahas di lembaga legislatif, dengan mendatangkan juru bicara (narasumber) yang ahli dalam bidangnya, seperti dosen fakultas hukum. e) Bentuk unjuk rasa : Unjuk rasa yang dilakukan oleh masyarakat bertujuan untuk menekan materi yang dibahas dalam pembentukan perundangundangan, dengan keinginan penolakan ataupun dukungan. f) Bentuk diskusi : Dalam metode legislative ini bentuk diskusi seminar dan lokakarya bertujuan untuk memperoleh kejelasan mengenai materi yang dibahas dalam pembentukan undang-undang. 23 3. Metode Post Legislative. a) Unjuk rasa atas undangundang baru : Unjuk rasa atas undangundang baru ini merupakan pernyataan

23 Ibid, hlm.594. 
sikap dari rakyat karena undang-undang yang baru dianggap sebagai penambahan masalah baru, bukan sebagai penyelesaian masalah. b) Tuntutan pengujian terhadap undang-undang : Undang-undang yang sudah di sahkan berlaku dan mengikat bagi setiap warga negara, tetapi karena Indonesia adalah negara demokrasi, rakyat yang merupakan kedaulatan tertinggi mempunyai hak untuk menanggapinya dengan melakukan uji materiil terhadap undang-undang. c) Sosialisasi undangundang : Pada metode post legislative ini sosiali dilakukan untuk menyebarluaskan undang-undang yang dikeluar oleh legislatif, jadi didalam metode ini masyarakat dapat melakukan pastisipasi dan mengetahui undangundang yang baru tidak hanya anggota yang ikut serta dalam proses pembentukan undang-undang.

\section{KESIMPULAN}

Implementasi kedaulatan rakyat yang diatur oleh UUD Negara Republik Indonesia Tahun 1945 dalam pasal 1 ayat (2) dalam konteks pelaksana demokrasi perwakilan di Indonesia berdasarkan UUD maka yang melaksakan adalah DPR yang mana sebelumnya dilaksanakan oleh MPR dan merupakan lembaga tertinggi sehingga keputusan MPR mutlak keinginan rakyat, sedangkan yang dilaksanakan oleh DPR juga belum maksimal karena dalam pelaksanaan seperti FGD hanya melibatkan kampus-kampus dan meminta pendapat yang dianggap ahli tanpa mempertimbangkan keinginan rakyat secara umum.

Implementasi yang dilaksanakan oleh wakil rakyat (DPR) diwujudkan dalam setiap pengambilan keputusan dari pembentukan undang-undang tetapi dalam pembentukan perundang-undangan masyarakat dapat ikut serta dengan cara aspirasi dan pengaduan yang dapat dilakukan dengan datang langsung atau juga dapat berbentuk surat atau sms dan juga online. Metode dalam keikut sertaan masyarakat dalam pembentukan undan-undang ini terdapat tiga metode 1. Ante Legislative 2. Legislative dan 3. Post Legislative.

\section{DAFTAR RUJUKAN}

\section{Buku}

Anwar, (2015) Teori dan Hukum Konstitusi, Malang, Setara Press.

Edi Indrizal, (2014) "Diskusi Kelompok Terarah Focus Group Discussion (FGD) (Prinsip-prinsip dan Langkah Pelaksanaan Lapangan), Padang, Universitas Andalas.

Kementerian Hukum dan HAM, (2019) Tanya Jawab Seputar Pembentukan Peraturan Perundang-undangan, Kemenkumham, Jakarta, Kementerian Hukum dan Ham.

Moh. Kusnardi dan Harmaily Ibrahim, (1983) Pengantar Hukum Tata Negara Indonesia, Jakarta, Pusat Studi Hukum Tata Negara.

Mukhti Fajar dan Ahmad Yulianto, (2013) Dualisme Penelitian Hukum Normatif 
dan Empiris, Yogyakarta, Pustaka Pelajar.

Ni'matul Huda, (2012) Hukum Tata Neagara Indonesia (Edisi Revisi), Jakarta, RajaGrafindo.

Ni'matul Huda, (2005) Hukum Tata Negara Indonesia, Jakarta, Pt Raja Grafindo Persada.

Peter Mahmud Marzuki, (2016) Penelitian Hukum, Jakarta, Kencana.

Soehino, (2001) Ilmu Negara, Yogyakarta, Liberty.

\section{Journal Article}

Halmes Lekipiouw Sherlock, (2016)

Konstruksi Kelembagaan Perwakilan

Dalam Pelaksanaan Kedaulatan

Rakyat, Sasi, Vol. 24 Nomor 1.

Mohamad Faisal Ridho, (2017) Kedaulatan

Rakyat Sebagai Perwujudan

Demokrasi Indonesia, Jurnal Adalah :

Vol. 1 Nomor 8e.

Putera Astomo, (2014) Pembentukan Undang-

Undang Dalam Rangka Pembaharuan

Hukum Nasional Di Era Demokrasi, Jurnal Konstitusi, Vol. 11, Nomor 3.

Yusdar, Kab. Maros (2016) Format Kelembagaan dan Politik Hubungan MPR Dengan DPR dan DPD Pasca Amandemen UUD Tahun 1945, Jurisprudentie, Vol. 3 Nomor 2.

Website tanpa autor

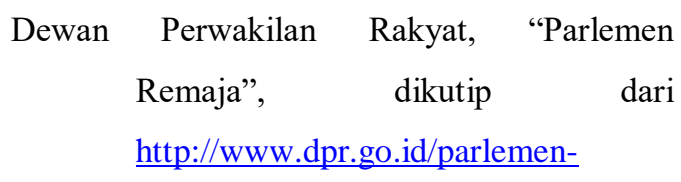

remaja/index diakses pada 8 mei 2020 jam. 01:46. 
